\title{
Hubungan Pengetahuan dan Sikap dengan Perilaku Mobilisasi Dini Pada Ibu Post Sectio Caesarea Di Ruang Rawat Gabung Kebidanan RSUD H Abdul Manap Kota Jambi
}

\author{
Bettywati E Tumanggor* \\ Jurusan Keperawatan Poltekkes Kemenkes Jambi \\ Jln.DR Tazar No 05 Buluran Telanai Pura Jambi \\ *Correspondence email: bettywati2212@gmail.com
}

\begin{abstract}
Abstrak. Mobilisasi dini merupakan faktor yang menonjol untuk mempercepat pemulihan post sectio caesarea, dan dapat mencegah komplikasi post sectio caesarea. Prinsip mobilisasi dini pada Ibu post sectio caesarea dilakukan secara bertahap dan teratur diikuti istirahat dan disesuaikan dengan kondisi fisik klien. Tujuan penelitian ini untuk mengetahui hubungan pengetahuan dan sikap dengan perilaku mobilisasi dini pada ibu post sectio caesarea di ruang rawat gabung kebidananp RSUD H. Abdul Manap Kota Jambi Tahun 2018. Metode penelitian menggunakan penelitian deskriptif dengan pendekatan kuantitatif. Desain penelitian menggunakan cross sectional. Sampel dalam penelitian berjumlah 40 orang dari seluruh populasi ibu post sectio caesarea yang dirawat diruang rawat gabung kebidanan RSUD H. Abdul Manap Kota Jambi Tahun 2018. Teknik Pengambilan sampel dengan accidental sampling. Analisis univariat bertujuan untuk memperoleh gambaran distribusi frekuensi dari setiap variabel yang diteliti dan analisis bivariat untuk menganalisis hubungan pengetahuan dan sikap dengan perilaku mobilisasi dini post sectio caesarea. Uji analisis megunakan uji statistik chi-square. Hasil penelitian menunjukkan dari 23 responden yang berpengetahuan yang baik sebanyak 18 responden $(78,2 \%)$ dengan perilaku mobilisasi dini baik dan 5 responden $(21,8 \%)$ dengan perilaku mobilisasi dini kurang baik. Uji statistik hubungan pengetahuan dengan perilaku mobilisasi dini diperoleh nilai $\mathrm{p}$-Value $=$ 0,006 dan $\mathrm{OR}=7,00$ artinya ada hubungan bermakna antara pengetahuan dengan perilaku mobilisasi dini pada post sectio caesarea. Hasil penelitian menunjukkan dari 31 reponden yang mempunyai sikap baik, 26 responden $(83,87 \%)$ dengan perilaku mobilisasi dini baik dan 5 responden $(16,12 \%)$ dengan perilaku mobilisasi dini kurang baik. Hasil uji statistik hubungan sikap dengan perilaku mobilisasi dini diperoleh nilai $\mathrm{p}$-Value $=0,000$ dan $\mathrm{OR}=22,235$ artinya ada hubungan bermakna antara sikap dengan perilaku mobilisasi dini pada ibu post sectio caesarea.
\end{abstract}

Kata Kunci: Mobilisasi Dini; Pengetahuan; Sikap; Post Sectio Caesarea

Abstract. Early mobilization is a prominent factor in accelerating post-section cesarean recovery and can prevent post-section cesarean complications. The principle of early mobilization in post section Caesarea is carried out gradually and regularly followed by rest and adjusted to the client's physical condition. The purpose of this study was to determine the relationship between knowledge and attitudes with early mobilization behavior in post-section Caesarea mothers in the combined obstetrics ward at H. Abdul Manap Hospital Jambi City in 2018. The research method used descriptive research with a quantitative approach. The research design used cross-sectional. The sample in the study amounted to 40 people from the entire population of post-section Caesarea mothers who were treated in the combined obstetrics ward of RSUD H. Abdul Manap Jambi City in 2018. The sampling technique was accidental sampling. The univariate analysis aims to obtain an overview of the frequency distribution of each variable studied and bivariate analysis to analyze the relationship between knowledge and attitudes with early mobilization behavior post section Caesarea. Test analysis using chi-square statistical test. The results showed that from 23 respondents with good knowledge, 18 respondents (78.2\%) with good early mobilization behavior, and five respondents (21.8\%) with poor early mobilization behavior. Statistical test of the relationship of knowledge with early mobilization behavior obtained $p$-Value $=0.006$ and $O R=7.00$, meaning that there is a relationship between knowledge and early mobilization behavior in postSectio Caesarea. The results showed 31 respondents had good attitudes, 26 respondents (83.87\%) with good early mobilization behavior, and five respondents (16.12\%) with poor early mobilization behavior. The results of the statistical test of the relationship between attitudes and early mobilization behavior obtained $p$-value $=0.000$ and OR $=22,235$, meaning that there was a relationship between attitudes and early mobilization behavior in post-section Caesarea mothers.

Keywords: Early Mobilization; Knowledge; Attitude; Post Sectio Caesarea

\section{PENDAHULUAN}

Proses persalinan yang sedang dihadapi seorang ibu kadang-kadang mengalami hambatan dan harus dilakukan dengan operasi, baik karena pertimbangan untuk menyelamatkan ibu dan janinnya ataupun keinginan pribadi pasien (Kasdu, 2003). Angka kelahiran diindonesia masih tinggi dan kira kira $15 \%$ dari seluruh wanita hamil mengalami komplikasi dalam persalinan, komplikasi persalinan membutuhkan penangan khusus dalam persalinan yaitu dengan tindakan Sectio Caesarea. Beberapa kasus seperti plasenta previa, preeklamsi, gawat janin dan janin besar yang dilakukkan dengan persalinan melalui vagina dapat menimbulkan resiko kematian pada ibu dan bayi oleh karena itu diperlukan satu cara untuk mengeluarkan hasil konsepsi melalui pembuatan sayatan pada dinding uterus 
Bettywati E Tumanggor, Hubungan Pengetahuan dan Sikap dengan Perilaku Mobilisasi Dini Pada Ibu Post Sectio Caesarea Di Ruang Rawat Gabung Kebidanan RSUD H Abdul Manap Kota Jambi

melalui dinding perut yang disebut sectio caesarea (Oxorn, 2010). Sectio caesarea adalah suatu persalinan buatan dimana janin dilahirkan melalui suatu insisi pada dinding perut dan dinding rahim dengan saraf rahim dalam keadaan utuh serta berat janin diatas 500 gram (Mitayani, 2009)

Menurut Word Health Organitation (WHO), standar rata-rata sectio caesarea disebuah negara adalah sekitar 5-15\% per 1000 kelahiran di dunia, rumah sakit pemerintah rata-rata $11 \%$, sementara di rumah sakit swasta bisa lebih dari 30\%. Permintaan sectio caesarea di sejumlah negara berkembang melonjak pesat setiap tahunnya (Judhita, 2009 dalam Sriyanti, 2016).

Secara umum jumlah persalinan sectio caesarea di Indonesia adalah sekitar $30-80 \%$ dari total persalinan. Menurut Kejadian sectio caesarea di Indonesia selalu mengalami peningkatan umumnya sectio caesarea dilakukan bila ada indikasi medis tertentu, sebagai tindakan mengakhiri kehamilan dengan komplikasi, selain itu sectio caesarea dilakukan tampa indikasi medis karena dianggap lebih mudah dan nyaman. Persalinans Sectio caesarea berkisar 30\% sampai $70 \%$ dari jumlah kelahiran hampir keseluruhannya disebabkan resiko tinggi melahirkan maupun komplikasi persalinan(Ayuningtyas, 2018) Angka kejadian sectio caesarea di indonesia menurut data survey nasional tahun 2007 adalah 927.000 dari 4.039 .000 persalinan. (Kemenkes RI, 2013) Hasil Riskesdas tahun 2013 menunjukkan kelahiran dengan metode operasi caesar sebesar 9,8 persen dari total 49.603 kelahiran sepanjang tahun 2010 sampai dengan 2013 (Novianti, 2017) Berdasarkan data Rekam Medis RSUD H. Abdul Manap kota Jambi Tahun 2018 persalinan dengan sectio caesarea cukup tinggi yaitu pada tahun 2016 berjumlah 256 orang, dan tahun 2017 sebanyak 199 orang.

Persalinan dengan sectio caesarea mempunyai resiko kematian dan komplikasi yang lebih besar yaitu resiko kesakitan dan menghadapi masalah fisik post operasi seperti timbulnya rasa sakit, perdarahan, kelelahan, sakit punggung dan gangguan tidur, keluhan kandung kemih bila reperitonialis terlalu tinggi, emboli paru, infeksi, dan ileus paralitik, (Hartati, 2015). Perawatan post sectio caesarea yang berkualitas dan pengawasan khusus mempunyai kedudukan yang sangat penting dalam usaha menurunkan angka kematian atau angka kesakitan dan komplikasi pada post sectio caesarea. Pengawasan yang kurang baik dan tidak cermat akan berdampak pada kematian ibu, oleh karena itu pemeriksaan dan monitoring dilakukan beberapa kali sampai tubuh ibu dinyatakan dalam keadaan sehat. Salah satu upaya untuk mencegah kejadian ini dapat dilakukan dengan mobilisasi dini (Wiknjosastro, 2002).

Mobilisasi dini ibu post sectio caesarea adalah suatu pergerakan atau adanya kegiatan yang dilakukan ibu setelah beberapa jam melahirkan dengan persalinan Sectio Caesarea. Mobilisasi dini merupakan faktor yang menonjol dalam mempercepat pemulihan post Sectio Caesarea dan dapat mencegah komplikasi post Sectio Caesarea. Mobilisasi dini sangat penting dalam percepatan hari rawat dan mengurangi resiko karena tirah baring lama seperti terjadinya dekubitus, kekakuan/penegangan otot-otot di seluruh tubuh, adanya gangguan berkemih, sirkulasi darah dan pernapasan terganggu (Mochtar, 1998) Prinsip mobilisasi dini pada klien post sectio caesarea dilakukan secara bertahap dan teratur diikuti istirahat dan disesuaikan dengan kondisi fisik klien. Mobilisasi dini bertujuan mempertahankan fungsi tubuh, memperlancar peredaran darah sehingga mempercepat penyembuhan luka, membantu pernafasan menjadi lebih baik, mempertahankan tonus otot, memperlancar eliminasi urin, mengembalikan aktivitas tertentu sehingga pasien dapat kembali normal dan atau dapat memenuhi kebutuhan gerak harian (Susan, 2004). Manfaat moblisasi dini antara lain dapat mempercepat proses pengeluaran lochea dan membantu proses penyembuhan luka dan mengurangi resiko infeksi. Ibu post sectio caesaraea yang melakukan moblisasi dini akan merasa lebih sehat, kuat dan memiliki kesempatan yang baik untuk merawat anaknya (Manuaba, 2009).

Dampak tidak melakukan mobilisasi dini akan mengakibatkan peningkatan suhu tubuh, menghambat pengeluaran darah dan sisa-sisa plasenta sehingga menyebabkan terganggunya kontraksi uterus, terjadinya perdarahan abnormal karena kontaksi yang terganggu (Aliahani, 2010). Mobilisasi dini merupakan hal yang penting dilakukan dalam mencegah komplikasi Sectio Caesarea. Mobilisasi dini merupakan aspek terpenting pada fungsi fisiologis dalam hal ini esensial mempertahankan Kemandirian (Carpenito, 2009)

Seorang ibu post sectio caesarea akan melakukan mobilisasi dini bila mempunyai pengetahuan tentang mobilisasi dini. Pengetahuan tentang moblisasi dini sangat penting agar ibu post sectio caesrea dapat melakukan mobilisasi dini dengan baik. Pengetahuan merupakan hasil tahu dan terjadi setelah orang melakukan pengindraan terhadap suatu obyek tertentu. Pengetahuan merupakan domain yang sangat penting dalam membentuk tindakan seseorang. Seseorang yang berpengetahuan baik cenderung akan melakukan perilaku yang dapat meningkatkan kesehatan sehingga tercapai kualitas hidup yang baik. Pengetahuan yang dimiliki seorang ibu dapat dipengaruhi oleh faktor seperti usia ibu, paritas, pendidikan dan pekerjaan (Notoatmodjo, 2010). Ibu Post Sectio Caesarea melakukan mobilisasi dini merupakan bentuk dari perilaku kesehatan. Ketidaktahuan dan rendahnya tingkat pengetahuan ibu tentang pentingnya mobilisasi dini pasca operasi menjadi salah satu faktor penghambat pelaksanaan mobilisasi dini (Potter \& Perry, 2006).

Berdasarkan penelitian Marfuah (2012) tentang hubungan tingkat pengetahuan dengan sikap ibu dalam mobilisasi dini pasca sectio caesarea dirumah sakit 
Bettywati E Tumanggor, Hubungan Pengetahuan dan Sikap dengan Perilaku Mobilisasi Dini Pada Ibu Post Sectio Caesarea Di Ruang Rawat Gabung Kebidanan RSUD H Abdul Manap Kota Jambi

umum daerah Dr. Moewardi tahun 2012, hasil penelitian menunjukkan bahwa Pengetahuan yang baik akan menunjang sikap yang baik, sikap yang baik menunjang mobilisasi dini yang baik, dan sikap yang kurang baik akan mengakibatkan mobilisasi dini yang kurang baik.

\section{METODE}

Penelitian ini menggunakan metode penelitian deskriptif, dengan pendekatan kuantitatif dan desain cross sectional yang bertujuan untuk menganalisis hubungan pengetahuan dan sikap dengan perilaku mobilisasi dini pada ibu post sectio caesarea di Ruang Kebidanan RSUD H. Abdul Manap Kota Jambi Tahun 2018. Sampel dalam peneltian adalah seluruh ibu post sectio caesarea yang dirawat di ruang rawat gabung kebidanan RSUD H. Abdul manap Kota Jambi Tahun 2018 pada bulan April sampai Oktober 2018. Teknik pengambilan sampel dengan Accidental Sampling. Analisis data secara univariat bertujuan untuk memperoleh gambaran distribusi frekuensi dari setiap variabel yang diteliti dan analisis bivariat digunakan untuk menganalisis hubungan pengetahuan dan sikap dengan perilaku moblisasi dini post sectio caesarea dengan uji statistik chi-square.

\section{HASIL DAN PEMBAHASAN}

Tabel 1. Karakteristik responden berdasarkan umur,pendidikan dan Paritas (n: 40)

\begin{tabular}{lll}
\hline $\begin{array}{c}\text { Karakteristik } \\
\text { Responden }\end{array}$ & Frekuensi & $\begin{array}{c}\text { Persentase } \\
(\%)\end{array}$ \\
\hline Umur & & 50 \\
$17-25$ & 20 & 42,5 \\
$26-35$ & 17 & 7,5 \\
$36-45$ & 3 & 100 \\
Total & 40 & \\
Pendidikan & & 10 \\
\hline SD & 4 & 10 \\
SMP & 4 & 70 \\
SMA & 28 & 10 \\
PT & 4 & 100 \\
Total & 40 & \\
Paritas & & 40 \\
\hline Primipara & 16 & 60 \\
Multipara & 24 & 100 \\
Total & 40 & \\
\hline
\end{tabular}

Berdasarkan tabel 1. dapat dilihat bahwa umur responden antara 17 sampai 25 tahun sebanyak 20 orang (50\%), SMA sebanyak 28 orang $(70 \%)$ dan Paritas sebagian besar multipara 24 orang $(60 \%)$

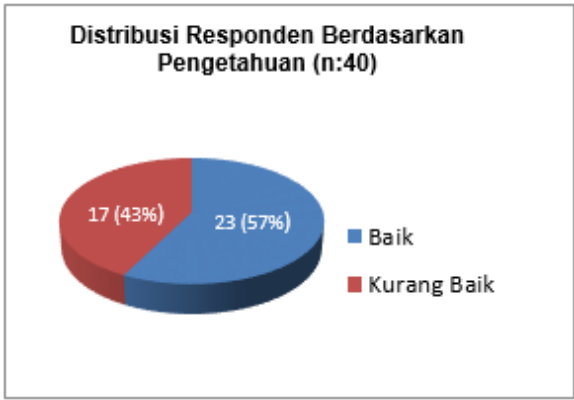

Gambar 1. Distribusi responden berdasarkan pengetahuan
Hasil penelitian pada gambar 1 dapat dilihat dari 40 responden terdapat 23 responden $(57,5 \%)$ yang pengetahuan baik

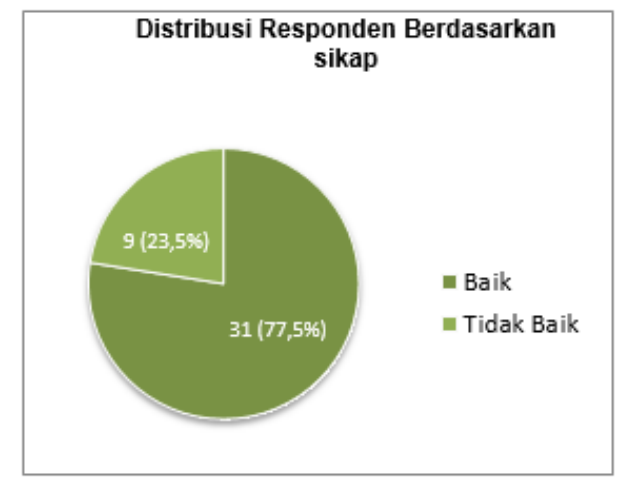

Gambar 2. Distribusi Responden berdasarkan sikap (n :40)

Hasil penelitian pada gambar 2 dapat dilihat bahwa dari 40 responden terdapat 31 responden $(77,5 \%)$ yang memiliki sikap yang baik

Tabel 2. Hubungan Pengetahuan Dengan Perilaku Mobilisasi Dini Pada Ibu post sectio caesarae di Ruang Rawat Gabung Kebidanan RSUD H. Abdul manap Kota Jambi Tahun 2018

$$
\text { (n: 40) }
$$

\begin{tabular}{|c|c|c|c|c|c|c|c|c|c|}
\hline \multirow[t]{3}{*}{ No } & \multirow[t]{3}{*}{ Pengetahuan } & \multicolumn{4}{|c|}{ Perilaku Mobilisasi Dini } & \multirow{2}{*}{\multicolumn{2}{|c|}{ Jumlah }} & \multirow{3}{*}{\multicolumn{2}{|c|}{ P Value }} \\
\hline & & \multicolumn{2}{|c|}{ Baik } & \multicolumn{2}{|c|}{ Kurang baik } & & & & \\
\hline & & Jlh & $\%$ & Jih & $\%$ & jith & $\%$ & & \\
\hline 1 & Baik & 18 & 78,2 & 5 & 21,8 & 23 & 100 & 0,006 & 7,000 \\
\hline 2 & Kurang baik & 4 & 23,5 & 13 & 76,4 & 17 & 100 & & \\
\hline Tota & & 22 & 55 & 18 & 45 & 40 & 100 & & \\
\hline
\end{tabular}

Dari tabel 2 dapat dilihat dari 23 responden mempunyai pengetahuan yang baik 18 responden $(78,2)$ dengan perilaku mobilisasi dini baik dan 5 responden $(21,8)$ dengan perilaku mobilisasi dini kurang baik, sedangkan dari 17 responden yang mempunyai pengetahuan kurang baik, 4 responden $(23,5 \%)$ dengan perilaku mobilisasi dini baik dan 13 responden $(76,47 \%)$ dengan perilaku mobilisasi dini kurang baik. Hasil uji statistik diperoleh nilai P-Value $=0.006$ dan $\mathrm{OR}=7,00$ artinya ada

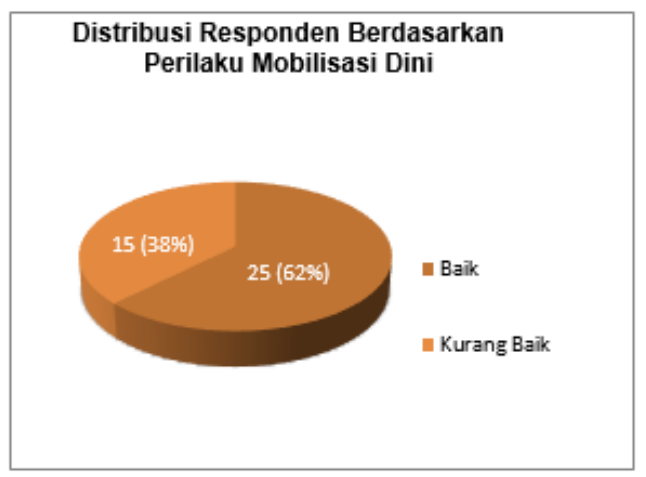

Gambar 3. Distribusi Responden berdasarkan Perilaku Mobilisasi Dini (n: 40)

Hasil penelitian pada gambar 3 dapat dilihat dari 40 responden terdapat 25 responden $(62,5,5 \%)$ dengan 
Bettywati E Tumanggor, Hubungan Pengetahuan dan Sikap dengan Perilaku Mobilisasi Dini Pada Ibu Post Sectio Caesarea Di Ruang Rawat Gabung Kebidanan RSUD H Abdul Manap Kota Jambi

perilaku mobilisasi dini baik hubungan yang bermakna antara pengetahuan dengan Perilaku mobilisasi dini pada ibu post sectio caesarea.

Tabel 3. Hubungan Sikap Dengan Perilaku Mobilisasi Dini Pada Ibu post sectio caesarea di Ruang Rawat Gabung Kebidanan RSUD H. Abdul Manap Kota Jambi Tahun 2018 (n: 40)

\begin{tabular}{|c|c|c|c|c|c|c|c|c|c|}
\hline \multirow[t]{3}{*}{ No } & \multirow[t]{3}{*}{ Sikap } & \multicolumn{4}{|c|}{ Perilaku Mobilisasi Dini } & \multirow{2}{*}{\multicolumn{2}{|c|}{ Jumlah }} & \multirow[t]{3}{*}{ P. Value } & \multirow[t]{3}{*}{ OR } \\
\hline & & \multicolumn{2}{|c|}{ Baik } & \multicolumn{2}{|c|}{ Kurang baik } & & & & \\
\hline & & Jlh & $\%$ & Jth & $\%$ & jith & $\%$ & & \\
\hline 1 & Baik & 26 & 83,87 & 5 & 16,12 & 31 & 100 & 0,000 & 22,35 \\
\hline 2 & Kurang baik & 2 & 22,22 & 7 & 77,77 & 9 & 100 & & \\
\hline Total & & 28 & 70 & 12 & 30 & 40 & 100 & & \\
\hline
\end{tabular}

Dari tabel 3 menunjukkan dari 31 reponden, sikap baik 26 responden $(83,87 \%)$ dengan perilaku mobilisasi dini baik dan 5 responden $(16,12 \%)$ dengan mobilisasi dini kurang baik, sedangkan dari 9 responden yang mempunyai sikap yang kurang baik, 2 responden $(22,22 \%)$ dengan perilaku mobilisasi dini baik dan 7 responden $(77,7 \%)$ yang perilaku mobilisasi kurang baik. Hasil uji statistik diperoleh nilai p-Value $=0.000$ dan $\mathrm{OR}=22,235$ artinya ada hubungan yang bermakna antara sikap dengan perilaku mobilisasi dini pada ibu post sectio caesarea

\section{Hubungan Pengetahuan Dengan Perilaku Mobilisasi Dini Pada Ibu post sectio caesarae di Ruang Rawat Gabung Kebidanan RSUD H. Abdul Manap Kota Jambi Tahun 2018}

Berdasarkan hasil uji statistik hubungan pengetahuan dengan perilaku mobilisasi dini pada ibu post sectio caesarea di ruang rawat gabung kebidanan RSUD H. Abdul Manap Kota Jambi diperoleh nilai Pvalue 0,006 yang artinya bahwa ada hubungan pengetahuan dengan perilaku mobilisasi dini pada ibu post sectio caesarea. Menurut Notoatmodjo (2010) pengetahuan kognitif merupakan faktor yang sangat penting untuk terbentuknya tindakan seseorang. Pengetahuan yang didasari dengan pemahaman yang tepat akan menumbuhkan perilaku baru yang diharapkan seperti perilaku mobilisasi dini yang dilakukan oleh ibu post sectio caesarea, hal ini sejalan dengan penelitian yang dilakukan Aisyah (2011) mengenai hubungan pengetahuan mobilisasi dini dengan tindakan mobilisasi dini pada ibu nifas satu hari post sectio caesarea diperoleh data bahwa responden yang berpengetahuan baik seluruhnya melakukan mobilisasi dini.

Menurut Wawan dan Dewi (2010) faktor-faktor yang mempengaruhi pengetahuan yaitu Faktor Internal seperti pendidikan. Pendidikan diperlukan untuk mendapatkan informasi yang menunjang kesehatan sehingga dapat meningkatkan kualitas hidup. Pada penelitian ini responden mempunyai pengetahuan yang baik karena sebahagian besar responden dengan latar belakang pendidikan SMA sebanyak 28 orang $(70 \%)$ dan sarjana 4 orang (10\%). Pendidikan yang tinggi akan mempermudah penyerapan informasi serta mempunyai pemahaman yang baik tentang informasi.

Pengalaman responden sebelumnya juga mendukung pengetahuan, Pada Penelitian ini sebagian besar sudah pernah melahirkan (multipara) sebanyak 24 orang $(60 \%)$ oleh karena itu responden sudah memahami mobilisasi dini dan sudah melakukan mobilisasi dini pada persalinan sebelumnya.

Hubungan sikap dengan perilaku mobilisasi dini pada ibu post sectio caesarea di ruang rawat gabung kebidanan RSUD H. Abdul Manap kota Jambi Tahun 2018

Berdasarkan hasil penelitian hubungan sikap dengan perilaku mobilisasi dini pada ibu post sectio caesarea di ruang rawat gabung kebidanan RSUD $\mathrm{H}$. Abdul Manap kota Jambi, diperoleh nilai P- value 0,000 yang artinya ada hubungan sikap dengan perilaku mobilisasi dini pada ibu post sectio caesarea. Menurut Notoatmodjo (2010) ada tiga komponen utama dalam menentukan sikap seseorang yaitu kepercayaan atau keyakinan, ide dan konsep terhadap suatu obyek, kehidupan emosional atau evaluasi suatu obyek, dan kecenderungan untuk bertindak. Reponden mempunyai sikap yang baik tentang mobilisasi dini disebabkan adanya kepercayaan dan keyakinan terhadap konsep mobilisasi dini sehingga mempunyai sikap yang baik tentang mobilisasi dini.

Sikap dapat berubah-ubah karena itu sikap dapat dipelajari dan sikap dapat berubah pada orang- orang bila terdapat keadaan-keadaan dan syarat-syarat tertentu yang memperngaruhi sikap pada orang itu (Notoatmodjo, 2010). Hal ini sesuai dengan sikap responden yang baik tentang mobilisasi dini karena adanya pengaruh pendidikan kesehatan yang diberikan petugas kesehatan diruang rawat gabung sehingga responden yang awalnya tidak mau melakukan mobilisasi dini akhirnya melakukan mobilisasi dini. Menurut Azwar (2017) Pengaruh orang lain yang dianggap penting juga mempengaruhi sikap seseorang, bahwa individu pada umumnya cenderung untuk memiliki sikap searah dengan sikap seseorang yang dianggap penting. Hal ini sejalan dengan dukungan dari keluarga yang merupakan orang penting dalam diri seorang ibu, sehingga ibu yang mendapat mendapat dukungan dari keluarga mempunyai sikap yang baik untuk melakukan mobilisasi dini

Faktor-faktor yang mempengaruhi sikap yaitu Pengalaman bahwa pengalaman dapat menjadi dasar pembentukan sikap apabila pengalaman tersebut meninggalkan kesan yang kuat. Responden yang mempunyai sikap yang baik tentang mobilisasi dini dapat disebabkan oleh pengalaman persalinan sebelumnya dimana mobilisasi dini memberikan manfaat pada dirinya. Pendidikan sangat menentukan system kepercayaan dan konsep mempengaruhi sikap. 
Bettywati E Tumanggor, Hubungan Pengetahuan dan Sikap dengan Perilaku Mobilisasi Dini Pada Ibu Post Sectio Caesarea Di Ruang Rawat Gabung Kebidanan RSUD H Abdul Manap Kota Jambi

(Nursalam, 2011) Secara garis besar sikap terdiri dari komponen kognitif (ide yang umumnya berkaitan dengan pembicaraan dan dipelajari) (Notoatmodjo, 2010). Sikap yang baik menunjang perilaku mobilisasi dini yang baik, atau sikap yang kurang baik akan mengakibatkan perilaku mobilisasi dini yang kurang baik, hal ini sejalan juga dengan perilaku kesehatan bahwa perilaku kesehatan merupakan suatu respon atau sikap seseorang terhadap stimulus yang berkaitan dengan pencegahan suatu penyakit dan peningkatan kesehatan. Responden dengan perilaku mobilisasi dini baik disebabkan karena adanya motivasi yang tinggi dalam diri responden untuk cepat pulih, selain itu pendidikan kesehatan yang di peroleh sebelumnya dari petugas kesehatan dapat mendukung perilaku mobilisasi dini ibu post sectio caesarea kearah yang lebih baik.

\section{SIMPULAN}

Berdasarkan hasil penelitian tentang hubungan pengetahuan dan sikap dengan perilaku mobilisasi dini pada ibu post sectio caesarea di ruang rawat gabung kebidanan RSUD H. Abdul Manap kota Jambi Tahun 2018, dapat disimpulkan sebagai berikut :

1. Pengetahuan ibu post sectio caesarea tentang mobilisasi dini di diruang rawat gabung kebidanan RSUD H. Abdul Manap Kota Jambi sebagian besar berpengetahuan baik yaitu sebanyak 23 responden $(57,5 \%)$

2. Sikap ibu post sectio caesaraea tentang mobilisasi dini di diruang rawat gabung kebidanan RSUD $\mathrm{H}$. Abdul Manap Kota Jambi sebagian besar mempunyai sikap yang baik sebanyak 31 orang $(77,5 \%)$

3. Perilaku mobilisasi dini ibu post sectio caesarea diruang rawat gabung kebidanan RSUD $\mathrm{H}$. Abdul Manap Kota Jambi sebagian besar melakukan mobilisasi dini yang baik sebanyak 25 orang $(62,5 \%)$

4. Ada hubungan antara pengetahuan dengan perilaku mobilisasi dini pada ibu post sectio caesara di ruang rawat gabung kebidanan RSUD $\mathrm{H}$. Abdul Manap Kota Jambi dengan $p$-Value $=0,006$

5. Ada hubungan antara sikap dengan perilaku mobilisasi dini pada ibu post sectio caesarea di ruang rawat gabung kebidanan RSUD $\mathrm{H}$. Abdul Manap kota Jambi dengan $p$-Value $=0,000$

\section{DAFTAR PUSTAKA}

Aisyah, Budi. (2011). Hubungan Pengetahuan tentang Mobilisasi Dini dengan Tindakan Mobilisasi Dini Pada Ibu

Nifas 1 Hari Post Sectio Caesarea. Dipetik 18 Maret 2018, dari

https://adoc.pub/hubungan-pengetahuan-tentangobilisasi-dini-dengan-tindakan.html

Aliahani, (2010). Mobilisasi Dini Pada Ibu Post Sectio Caesarea. Dipetik 20 Maret 2018, https://honey72.wordpress.com/2010/06/15/mobili sasi-dini-pada-ibu-post-scl

Ayuningtyas, D.,dkk (2018) Etika Kesehatan Pada Persalinan Melalui Sectio Caesrea Tampa Indikasi Medis. Dipetik

tanggal $24 \quad$ April 2018, dari https://media.neliti.com/media/publications/23844 7-etika-kesehatan-pada-persalinan-melalui2cb2a22b.pdf

Azwar, (2017). Metode penelitian psikologi. Yogyakarta: Pustaka Pelajar.

Carpenito. (2009). Pengantar Kebutuhan Dasar Manusia: Aplikasi dan Proses Keperawatan. Jakarta : Salemba Medika

Hartati, S. \&Maryunani A.(2015) Asuhan Keperawatan Sectio Caesarea. Jakarta : Trans Info Media

Juditha, I. (2009). dalam Sriyanti 2016 Pengaruh mobilisasi dini terhadap penyembuhan luka PostSc di RSUD dr. Zainoel Abidin Banda Aceh. Dipetik tanggal 20 Maret 2018, dari Jurnal Pionir http://jurnalpionir.blogspot.com/2016/10/cutsriyanti-volume-3-nomor-2-januari.html

Kasdu, (2003). Operasi Caesar : masalah dan solusinya, Puspa Swara: Jakarta

Manuaba, I. (2009). Ilmu Kebidanan, Penyakit Kandungan dan Keluarga Berencana Untuk Pendidika Bidan. Jakarta: EGC.

Marfuah, I. (2012). Hubungan tingkat pengetahuan dengan sikap ibu dalam mobilisasi dini pasca sectio caesarea dirumah sakit umum daerah Dr.Moewardi. Dipetik tanggal 25 Maret 2018, dari Indonesia One search https://onesearch.id/Record/IOS2728.21980

Mitayani, (2009). Asuhan Keperawatan Maternitas. Salemba Medika: Jakarta.

Mochtar, (1998). Sinopsis Obstetri : Obstetri Operatif, Obstetri Sosial, editor, Delfi Intan. Ed. 2. EGC. Jakarta.

Notoatmodjo, soekedjo, (2010). Pendidikan Perilaku Kesehatan. Rineka Cipta: Jakarta.

Novianti, (2017). Determinan persalinan sectio caesarea di indonesia (analisis lanjut data riskesdas 2013 Dipetik tanggal 18 Maret 2018, dari jurnal Kesehatan Reproduksi https://media.neliti.com/media/publications/10855 6-ID-none.pdf

Nursalam, (2011). Konsep dan Penerapan Metodologi Penelitian Ilmu Keperawatan:Pedoman Skripsi, Tesis dan Instrumen Penelitian, Salemba Medika: Jakarta.

Oxorn, H. (2010) Ilmu Kebidanan Patologi dan Fisiologi Persalinan. Yogjakarta: Yayasan Essentia Medica

Potter, dan pery (2006). Fundamental Perawatan. Edisi IV. Jakarta: Penerbit Buku Kedokteran EGC. 
Bettywati E Tumanggor, Hubungan Pengetahuan dan Sikap dengan Perilaku Mobilisasi Dini Pada Ibu Post Sectio Caesarea Di Ruang Rawat Gabung Kebidanan RSUD H Abdul Manap Kota Jambi

Susan J. Garrison, (2004). Dasar-dasar Terapi dan Latihan Fisik. Jakarta : Hypocrates. Sylvia. 1995. Fisiologi Kedokteran Edisi 14. Jakarta: EGC

Wawan, A dan Dewi, M, (2010). Teori dan Pengukuran Pengetahuan, Sikap dan Perilaku Manusia. Jakarta: Nuha Medika.

Wiknjosastro, Hanifah. (2002). Ilmu Kebidanan, editor. Absul Bari Syaifuddin Trijatmo Rochim Hadhi. Ed. 3. Yayasan Bina pustaka Sarwono Prawirohardjo: Jakarta.

Www. Depkes.go.id. (2013). Profil Kesehatan. Jakarta: Kemenkes RI. 